\title{
Export Spillovers from Global Shocks for the Middle East and Central Asia
}




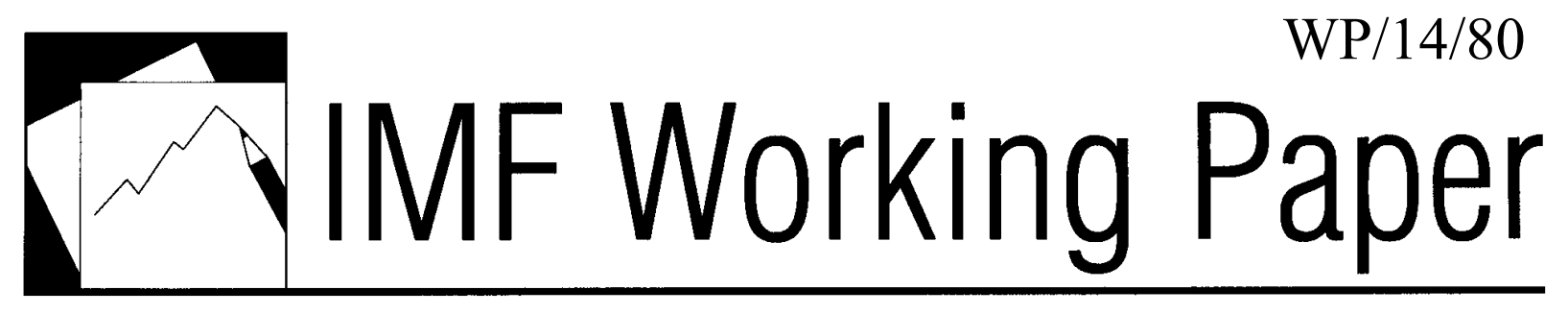

\section{Export Spillovers from Global Shocks for the Middle East and Central Asia}

Alberto Behar and Jaime Espinosa-Bowen 


\title{
IMF Working Paper
}

Middle East and Central Asia

\section{Export Spillovers from Global Shocks for the Middle East and Central Asia Prepared by Alberto Behar and Jaime Espinosa-Bowen ${ }^{1}$}

Authorized for distribution by Natalia Tamirisa

May 2014

\section{This Working Paper should not be reported as representing the views of the IMF.}

The views expressed in this Working Paper are those of the author(s) and do not necessarily represent those of the IMF or IMF policy. Working Papers describe research in progress by the author(s) and are published to elicit comments and to further debate.

\begin{abstract}
This paper quantifies the effect of realized and potential global growth disappointments on export volumes from the Middle East, North Africa, the Caucasus, and Central Asia. Estimates of export elasticities with respect to trading partner GDP indicate non-oil export volumes are relatively responsive while service exports are less responsive. Downward revisions to global GDP growth for 2011-14 have impeded export performance, and the possibility of disappointing GDP growth in Europe and emerging markets presents further downside risks for exports. The Maghreb countries are particularly sensitive to developments in Europe, while CCA countries are more susceptible to growth in the BRICS.
\end{abstract}

JEL Classification Numbers: F17 F44

Keywords: Gravity model, exports, spillovers, trade, Middle East, North Africa, Caucasus, Central Asia

Authors’ E-Mail Addresses: abehar@imf.org Jaime.Espinosa-Bowen@tn.gov

\footnotetext{
${ }^{1}$ The authors thank Rudolph Bems, Carlos Caceres, Paul Cashin, Alexander Culiuc, Christian Ebeke, Sanaa Farid, SeokHyun Yoon, Kia Penso, Mehdi Raissi, Pedro Rodriguez, Natalia Tamirisa, Petia Topalova, Francis Vitek, and participants in the IMF Middle East and Central Asia Discussion Forum. Any errors remain our own.
} 


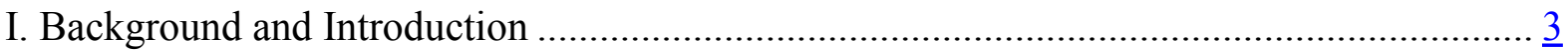

II. Trade Patterns in the Middle East and Central Asia......................................................... $\frac{5}{6}$

A. Assessing Exposure and Vulnerability............................................................... $\underline{6}$

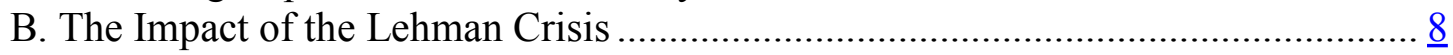

C. Recent Developments ................................................................................. 11

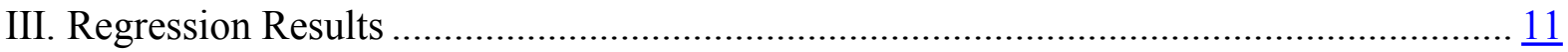

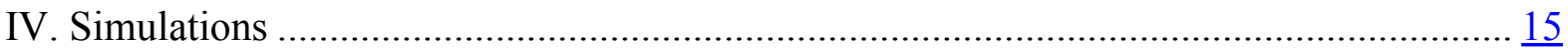

A. Euro Area Shocks.....................................................................................

B. Emerging Market Shock ................................................................................. $\frac{21}{21}$

C. Downward Revisions of the Global Outlook …………………………………... 23

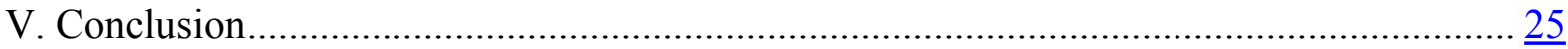

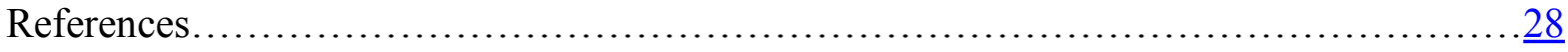

Tables

Table 1: Geographical Distributions of Exports of Goods, 2007-11.................................... 7

Table 2: Preferred Export Elasticity Estimates ................................................................. $\frac{13}{14}$

Table 3: Alternative ARDL Estimates ………………................................................. 14

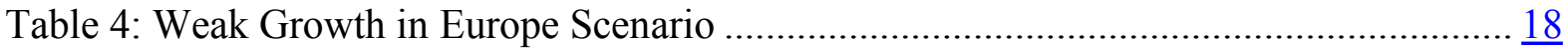

Table 5: Re-emergence of Financial Stress in Euro Area Scenario ……………………...... $\frac{20}{22}$

Table 6: BRICS Slowdown Scenario ............................................................................

Table 7: Implications of Revisions to Global Growth................................. 24

Figures

Figure 1: Share of Non-Hydrocarbon Exports by Destination................................................ $\frac{8}{2}$

Figure 2: All Goods Exports to the World ……………............................................... $\frac{9}{9}$

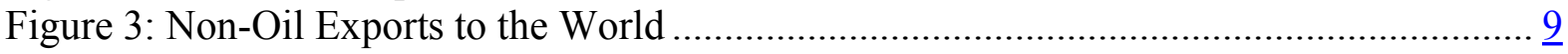

Figure 4: Non-Oil Exports to Europe ……………….............................................. 11

Figure 5: Non-Oil Exports to BRICS.......................................................................... 11

Figure 6: Two-year Cumulative Non-Oil Export Impact of Euro Area Financial Stress,

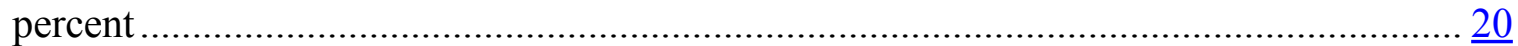

Figure 7: Two-Year Cumulative Non-Oil Export Impact of BRICS Schock, percent …….... 22

Figure 8: Export Loss from Revisions to Global Growth .................................................... 24 


\section{BACKGROUND AND INTRODUCTION}

1. After the great recession, recovery has been slow and subject to downward revisions. Following the collapse of Lehman Brothers in 2008 and the resulting major global recession, recovery has been anemic in the world's advanced economies. While emerging market and developing countries have been growing substantially faster than developed nations, many are expected to slow down. The outlook for global growth has been revised downwards substantially since 2011 such that economic performance is expected to remain weak. Furthermore, it remains subject to substantial downside risks (IMF, 2013a).

2. Europe's growth remains sluggish and subject to downside risks. Europe in particular experienced negative growth at the end of 2011 and European Union GDP growth is estimated to be about zero in 2013. Europe has been vulnerable to a crisis associated with fiscal problems in Greece, Spain and other countries. Actions taken by governments and the European Central Bank (ECB) have helped stabilize conditions in the euro area and growth is forecast to return in 2014. However, there are still concerns that financial stress could reemerge as a result of stalled or incomplete delivery of policy commitments, resulting in a substantial fall in GDP. A less acute shock could manifest itself through a protracted period of slower European growth due to public debt and private sector deleveraging. Fears of deflation are also growing.

3. Emerging market growth has slowed down and is subject to downside risks. Growth in emerging markets has been slowing down for structural and cyclical reasons. Observers fear a further sharp slowdown in some of the major emerging markets. For example, private investment in the BRICS (Brazil, Russia, India, China and South Africa) has repeatedly surprised on the downside in recent years and could do so again by a substantial margin.

4. The emphasis of this paper is on the effects of global growth on export volumes from the Middle East and Central Asia. We estimate separate impacts for sub-regions, namely the Maghreb, the Mashreq, the Gulf Co-operation Council (GCC) and the Caucasus and Central Asia (CCA) or, alternatively, the Middle East and North Africa (MENAP) oil importers and oil exporters. These countries constitute those in the IMF's Middle East and Central Asia Department (MCD). Our core analysis is of non-petroleum exports. To a limited extent, we discuss the impact on services exports and oil exports.

5. An emphasis on exports is warranted. Although the Great Recession started as a financial crisis in a few rich countries, this was for most countries a trade crisis brought about primarily by the ensuing collapse in global demand (Baldwin, 2009). Between the start of 2008 and early 2009, world trade fell by 15 percent, which was almost four times the change in global GDP. On aggregate, the MCD region's share of goods exports destined to Europe is higher than that of any region except Europe itself. Remittances are important for the region relative to other regions but not relative to trade, while financial exposures are generally 
limited (Behar, 2013). Therefore, though there are several channels through which crises can operate, trade can lay claim to being the most important for many countries in the MCD region.

6. This paper has in view an established literature on the relationship between exports, geography, and income. Since at least Tinbergen (1962) and the formal gravity models that followed, a robust empirical finding is that countries trade more with other countries that are physically and culturally closer, and that that the elasticity of exports to trading partner income is unity (Head and Mayer, 2013). However, this finding is at odds with what happened during the global financial crisis, and there is also evidence that trade has grown by more than income (Irwin, 2002).

7. There are a number of other channels through which shocks in other regions could affect MCD countries. Linkages between the rest of the world and the region are discussed in Behar (2013). These include remittances to the Maghreb and CCA from Europe and Russia, respectively (Abdih and others, 2012); finance, and foreign direct investment, where the links are relatively limited but played a role after the global financial crisis; and oil prices, which fell substantially in 2009 but would have different impacts for oil exporters and oil importers.

8. Formal spillover analysis does not adequately cover MCD countries. Berument and Ceylan (2008) examine the reaction of domestic interest rates in a set of MENA countries to U.S. monetary policy surprises. Tas (2010) examines the effects of global GDP and oil price shocks on Gulf Cooperation Council (GCC) countries. The International Monetary Fund has expanded its analysis of cross-border spillovers, but with limited emphasis on MCD countries. The Global Economy Model (GEM) showcased for example in the World Economic Outlook (IMF, 2012a) has an aggregate for the entire region. The 35-S Model, a macroeconometric model included in the 2013 Spillover Report (IMF, 2013b), includes Saudi Arabia but no other MCD countries (Vitek, 2013). EMERGMod, which was included in the April 2013 (IMF, 2013c) and October 2013 (IMF, 2013a) World Economic Outlooks allow for greater coverage of emerging markets. Such models indicate that a BRICS shock could reduce GDP in the MCD countries by about $1 / 2$ percent to 1 percent, and that the effects of slow European growth would be modest (Behar, 2013). However, there is still insufficient allowance for variation across MCD countries. To fill this gap, Cashin, Mohaddes and Raissi (2012) estimate a Global Vector Autoregression model of GDP spillovers to a number of countries in the Middle East and North Africa. Calibrations based on this model are included in IMF (2012b). Similarly, Albino-War and others (2012) have launched an enquiry into the impacts of Russia and the euro area on the Commonwealth of Independent States and Baltic countries.

9. Section two presents the data and descriptive statistics. It starts by describing current non-oil export shares of MCD countries to other regions including Europe and key BRICS countries. This gives a good first impression but is misleading because goods can go indirectly via third countries in the form of intermediate exports. Similarly, it ignores the 
indirect effects of a slowdown in these third countries induced by trade and other channels, so we indicate exposure to important other regions as well. The section describes how these exposures have evolved over the last decade. It also documents the large falls in exports observed during the 2008-09 crisis and shows that the subsequent recovery in exports was short-lived, in part because of a deteriorating global outlook.

10. Section three uses regression analysis to estimate the historical short-run and long-run response of trade flows to trading partner GDP. Estimates are attained using a variety of panel data econometric techniques using a version of the gravity model, which is a workhorse model of the trade literature (Head and Mayer, 2013). We use a collapsed rather than bilateral formal gravity model because we are interested in aggregate rather than bilateral exports, because the focus is not on bilateral trade costs but on trading partner GDP, and because bilateral data is not available for services (Freund, 2009; Abiad, Mishra, and Topalova, 2010). The elasticity is about 2 for all goods exports, 3.3 for non-oil goods exports, and 1.2 for services exports in the short run. Long-run estimates are close to 1 for goods exports, which is consistent with formal gravity models.

11. Section four presents estimates of global shocks on MCD exports. We estimate the effects that would be brought about in the event of an acute euro area crisis, moderate growth in Europe, or slower growth in the BRICS. To do so, we combine our regression results with the predictions of the resulting slowdown in major MCD trading partners produced by existing models and described in various issues of the World Economic Outlook. The results show that the Maghreb countries are most exposed to developments in Europe, where a 1 percent fall in GDP corresponds roughly to a $23 / 4$ percent reduction in non-oil exports in the short run. CCA countries are also linked to Europe but are more exposed to shocks in the BRICS countries. We also estimate that the downward revisions in global growth for 201114 have cost the CCA countries four months of non-oil exports and been similarly costly for the Maghreb countries. Although the same analysis is not possible for oil and services export volumes, we discuss how they would be affected

12. Section five concludes the paper, including the implications of our results for aggregate demand and external balances, reasons why the estimates may be too low, and suggestions for going beyond our simple framework towards one based on fully specifiedexport demand and supply equations.

\section{Trade Patterns in the Middle East and Central Asia}

13. This section describes geographical exposures and recent export developments. The exposure of MCD regions to other regions is analyzed with data on the geographical composition of their export bundles. This section also describes how exposures have changed over the last 15 years. To understand how exports have fared in response to global shocks, we describe export performance following the global financial crisis in 2008-9 and in response to more recent developments in Europe and the BRICS countries. 
14. We use annual trade data for the assessment of exposures as well as for the regression and simulation analysis. In the regression analysis, we use a panel of approximately 150 countries from 1994-2009. We use IMF Direction of Trade Statistics data for goods trade flows. For robustness, we also referred to the United Nations COMTRADE data for total goods trade flows. The IMF data have the potential advantage of using mirrored import data on a number of occasions when data are missing from COMTRADE exporters. However, COMTRADE allows us to generate non-petroleum exports, which we proxy as the total minus products under SITC code 33. This bilateral data allows us to describe the destinations of goods exports, including just non-petroleum goods, and to incorporate this in our simulations. However, our analysis of services trade is more limited because of the lack of bilateral trade data. We deflate the trade data in U.S dollars using unit values of exports and draw GDP data from the World Economic Outlook 2012 database. Furthermore, we extract information on geodesic distance from CEPII and components of aggregate demand were drawn from the April 2012 edition of the WEO. Data for durable goods were taken from the WEO October 2010 version.

15. Primarily for the descriptions of developments in the last few years, monthly data on bilateral flows of goods, including oil-derived products, come from the Global Trade Atlas database. This database combines high frequency data with the ability to select or exclude specific products. Because it does not have complete data on exports from MCD, we use mirror import data from major trading partners and from the world as a whole. Trade flows are denominated in U.S. dollars and are presented for January 2008 to June 2013. In addition to total goods trade, we analyze non-petroleum goods trade by subtracting all commodities in code 27 of the Harmonized System (HS) nomenclature.

\section{A. Assessing Exposure and Vulnerability}

16. The MCD region includes a diverse group of countries that we have divided into smaller groups. These groups are the Maghreb countries in North Africa (Algeria, Libya, Mauritania, Morocco, and Tunisia); the Mashreq (Egypt, Jordan, Lebanon, and Syria); the Gulf Cooperation Council (GCC) countries (Bahrain, Kuwait, Oman, Qatar, Saudi Arabia, and the United Arab Emirates); Caucasus and Central Asia oil exporters (Azerbaijan, Kazakhstan, Turkmenistan and Uzbekistan); Caucasus and Central Asia oil importers (Armenia, Georgia, Kyrgyz Republic, and Tajikistan); and, for descriptive statistics, a diverse group of other countries (Afghanistan, Djibouti, Iran, Iraq, Pakistan, Sudan, and Yemen).

Simulation results also allow for a separate classification of MENAP oil exporters (GCC and Algeria, Iran, Iraq, Libya, and Yemen) and MENAP oil importers (Afghanistan, Djibouti, Egypt, Jordan, Lebanon, Mauritania, Morocco, Pakistan, Syria, and Tunisia). Unfortunately, some countries have no or limited data. 
17. Europe is an important export destination for MCD. Europe accounts for almost a third of all MCD goods exports, and it is the largest destination for most sub-groups, but there is substantial heterogeneity. ${ }^{2}$ For the MENAP region, Europe is the destination for 30 percent of goods export volumes. It accounts for more than two thirds of Maghreb non-oil exports due in large part to geographical proximity and historical ties (Table 1). For the rest of the MENAP region, Europe's share is smaller. For the CCA oil exporters, Europe, Russia and China are the main destinations for non-oil exports. For the CCA oil importers, Europe alone receives the largest share of exports.

Table 1: Geographical Distributions of Exports of Goods, 2007-11

\begin{tabular}{|c|c|c|c|c|c|c|}
\hline & Maghreb & Mashreq & GCC & $\begin{array}{c}\text { Other } \\
\text { MENAP }\end{array}$ & $\begin{array}{c}\text { CCA oil } \\
\text { exporters }\end{array}$ & $\begin{array}{r}\text { CCA oil } \\
\text { importers }\end{array}$ \\
\hline \multicolumn{7}{|c|}{ Non-petroleum goods } \\
\hline Europe & 68.0 & 19.7 & 10.4 & 20.4 & 23.2 & 37.0 \\
\hline China & 1.9 & 1.6 & 5.0 & 7.7 & 20.2 & 1.8 \\
\hline Other Asia & 0.8 & 1.7 & 5.1 & 5.7 & 0.5 & 0.1 \\
\hline Russia & 0.7 & 0.8 & 0.0 & 0.9 & 23.5 & 12.8 \\
\hline USA & 2.2 & 7.0 & 3.2 & 15.0 & 2.1 & 5.0 \\
\hline Turkey & 1.7 & 4.0 & 1.1 & 3.0 & 3.9 & 6.6 \\
\hline Other non-MCD & 14.2 & 14.1 & 32.3 & 18.2 & 8.7 & 11.6 \\
\hline MCD & 10.5 & 51.2 & 42.8 & 29.2 & 17.8 & 25.2 \\
\hline Total & 30.1 & 78.7 & 84.6 & 71.9 & 56.5 & 61.2 \\
\hline \multicolumn{7}{|l|}{ All goods } \\
\hline Europe & 60.5 & 29.8 & 6.3 & 13.4 & 55.3 & 36.7 \\
\hline China & 3.1 & 1.6 & 15.1 & 16.3 & 11.2 & 1.9 \\
\hline Other Asia & 0.7 & 1.4 & 6.2 & 7.5 & 1.7 & 0.1 \\
\hline Russia & 0.2 & 0.6 & 0.0 & 0.6 & 7.1 & 12.9 \\
\hline USA & 14.3 & 6.9 & 4.1 & 16.5 & 3.4 & 5.0 \\
\hline Turkey & 2.5 & 3.8 & 0.4 & 2.1 & 2.4 & 6.6 \\
\hline Other non-MCD & 14.4 & 17.4 & 51.6 & 19.3 & 11.4 & 11.5 \\
\hline MCD & 4.5 & 38.6 & 16.3 & 24.5 & 7.5 & 25.5 \\
\hline Total & 36.5 & 68.6 & 78.6 & 70.3 & 33.6 & 61.5 \\
\hline
\end{tabular}

Sources: UN Comtrade, and IMF staff calculations.

18. China and the rest of Asia are relatively more important destinations for MENA and CCA non-oil exports compared to previous years. The share of exports to China for example have almost doubled for GCC and CCA oil exporters, accounting in 2007-11 for 5 and 20 percent of total exports, respectively. Russia continues to be an important destination, while the other BRICS countries are not big customers. MCD non-oil exports to Europe have decreased. For instance, shares have declined since the 1998-02 period from almost 30 percent to 20 percent in the Mashreq and 33 percent to 23 percent for the CCA oil exporters.

\footnotetext{
${ }^{2}$ Deficient bilateral data for services precludes analysis of the geographical composition of service exports. Nonetheless, there is reason to believe that a good portion of tourism comes from Europe, especially to the Maghreb.
} 
Figure 1: Share of Non-Hydrocarbon Exports by Destination

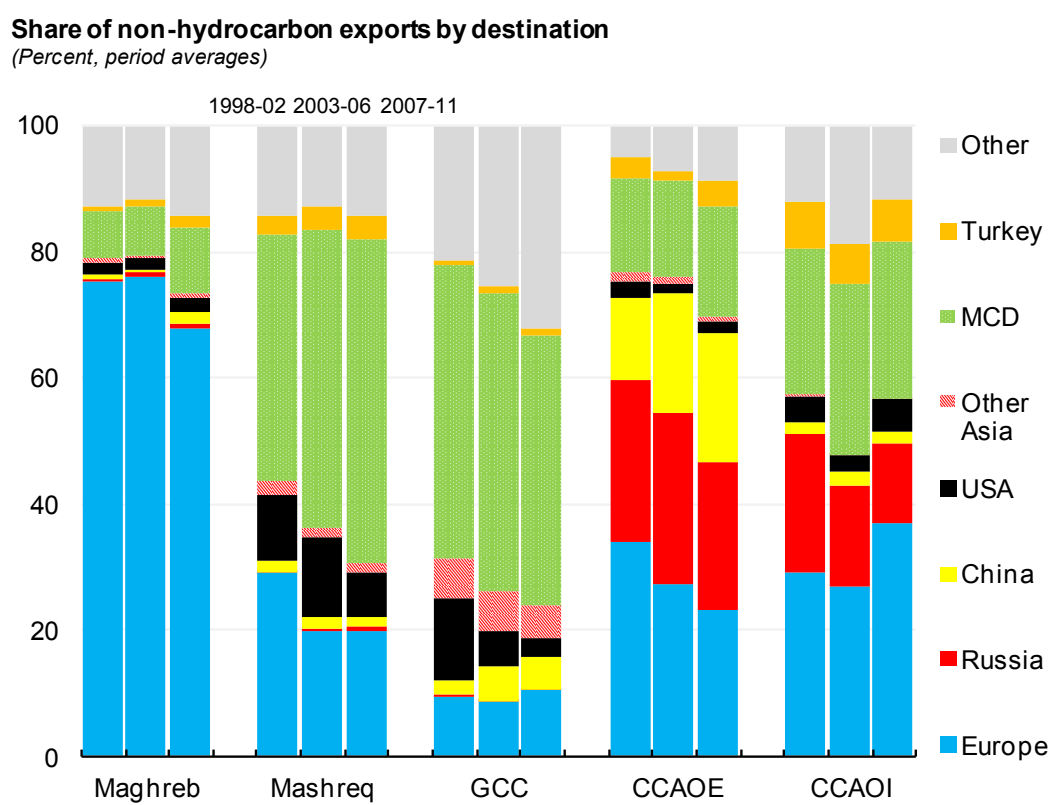

19. We focus on external exports, although within-MCD exports can be important in some cases. The Middle East, North Africa, Caucasus and Central Asia is a vast set of countries that comprises a large share of the export basket in some MCD countries. ${ }^{3}$ Intra-MCD trade of non-oil goods is especially important in the Mashreq, who export to the GCC. This is informative, but the emphasis of this study is on external shocks via direct effects to Europe or the BRICS and indirect effects to other regions. Nonetheless, there would be a further impact on exports because any induced growth slowdown in our region would lead to a fall in intra-regional trade.

\section{B. The Impact of the Lehman Crisis}

20. The Lehman crisis had a dramatic impact on MCD exports. Following the collapse of Lehman Brothers in September 2008, world output fell by 0.6 percent (year-on-year) in 2009. At the same time, the volume of goods and services traded globally fell by over 10 percent. $^{4}$ The volume of MCD goods and services exports fell by almost 7 percent and the value fell by almost a third. These year-on-year changes do not reflect the suddenness and severity of the drops as well as in Figure 2. From July 2008 (peak) to February 2009 (trough), the nominal

\footnotetext{
${ }^{3}$ For evaluating intraregional trade, it is arguably more appropriate to use smaller country groups. The consensus is that countries in the Middle East tend to trade too little with each other (Behar \& Freund, 2011). It has also been argued that trade between countries in the Caucasus and Central Asia is low given its geographic characteristics (IMF, 2011; Babetskii, Babetskaia-Kukharchuk and Raiser, 2003).

${ }^{4}$ The fall between September 2008 and January 2009 exceeded 15 percent before rebounding strongly, which was almost four times the corresponding fall in world GDP (Gregory and others, 2010).
} 
value of goods exports fell by 40 percent in the MENAP Oil Importers, 60 percent in the MENAP Oil Exporters and 70 percent in the CCA.

Figure 2: All Goods Exports to the World

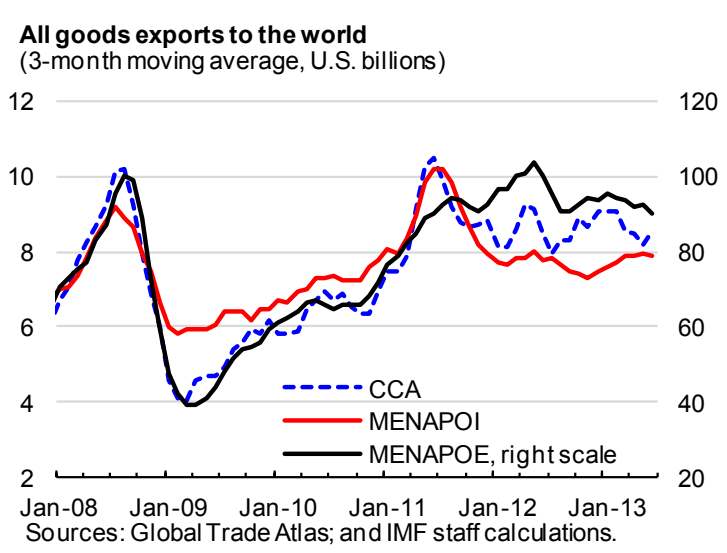

Figure 3: Non-Oil Exports to the World

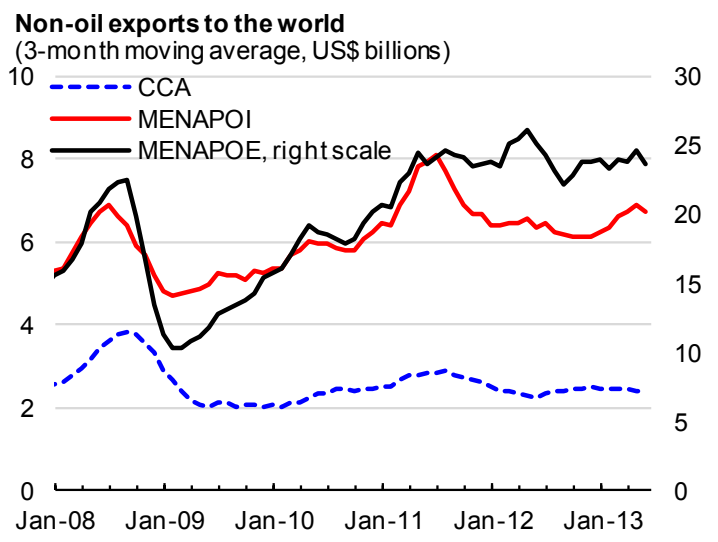

21. Crude oil export volumes and prices fell. While the annual average oil price fell by a third between 2008 and 2009, volumes also fell. For the oil exporters in the Middle East and North Africa, export volumes fell by almost 10 percent. This is not exclusively due to Saudi Arabia; GCC exports excluding the biggest producer fell by 11.5 percent. The CCA oil exporters did not reduce their oil exports, but the MCD region as a whole still reduced oil export volumes by 8 percent. Therefore, while it is clear that the oil price change was more dramatic, oil volumes also fell.

22. Non-oil exports, which we emphasize in this paper, fell precipitously during the Lehman crisis. From July 2008 to February 2009, MCD's non-oil exports were cut in half. In particular, they fell by 55 percent in the MENAP oil exporters, 35 percent in the MENAP oil importers, and 41 percent in the CCA.

23. Why was the goods trade response so large? The fall in global trade volumes was many times the fall in global output. Similarly, the volume of MCD exports fell by much more than output in its trading partners. Gravity models of trade imply that the trade response to output should be unity and the empirical support for this is strong. However, this is arguably only theoretically appropriate in the long run, while estimates of unity are more likely to be found in cross-sectional estimates or estimates using averages of multiple years. ${ }^{5}$ In the short run, for example using annual data, why can the elasticity be greater than unity? In particular, why was the global contraction in goods demand so large?

\footnotetext{
${ }^{5}$ There are a multitude of papers, but see for example Anderson \& van Wincoop (2003). In a MENA context, see Behar \& Freund (2011).
} 
- $\quad$ Demand composition effects played an important role. The contraction in final demand during the recent crisis was asymmetric across sectors, with demand for durables falling by considerably more than demand for other goods or for services. During the course of 2009, the average across 34 countries of the change in durables was almost five times the average change in GDP. ${ }^{6}$ Since the mid 1990s, the global average elasticity of durables to GDP has been about three. As argued in Bems, Johnson \& Yi (2010), because durable goods have a larger weight in trade flows than in final demand, the asymmetrical changes in demand across sectors caused global trade to fall by more than aggregate demand.

- $\quad$ Evidence on intermediates is mixed. The majority of global goods trade is in intermediate goods, which are only indirectly linked to final demand. Furthermore, intermediates have different shares in durables and other components of demand. Together with the composition effects, this can lead to larger or smaller effects of intermediates. In the framework of Bems and others (2010), intermediates played a relatively small role partly because the share of intermediates in durables is smaller than the share of final goods in durables. Altomonte and Ottaviano (2009) find indirect evidence that trade within global supply chains was relatively resilient. In contrast, Levchenko, Lewis and Tesar (2009) find that US trade fell by more in sectors that have strong vertical linkages.

- The role of trade costs was moderate. Even after controlling for changes in GDP, crises have a significant effect on trade (Abiad, Mishra, and Topalova, 2010). In a gravity model framework, this is consistent with a rise in trade costs (Jacks, Meissner \& Novy, 2009), including murky protectionism and a lack of trade finance. Trade is sensitive to protectionism, but the increase in incidences of protectionism was modest. That does not mean that such restraint would repeat itself in the wake of renewed protectionist pressure (Gregory and others, 2010). Trade finance can have important effects but, due in large part to concerted efforts by policy-makers, it was not withdrawn dramatically during the crisis (Mora and Power, 2009).

24. Services trade is more resilient. Borchert \& Mattoo (2009) suggest services may be less sensitive to the business cycle because demand for many internationally services is less cyclical, in part because they generally can't be stored are less discretionary parts of businesses, and less dependent on external finance. Furthermore, demand for all services fell by less than other sectors of the economy (Bems et al, 2010).

\footnotetext{
${ }^{6}$ Given that durables average approximately 10 percent of GDP, this is consistent with IMF (2010) in that the change in durables was approximately ten times the change in the rest of GDP.
} 


\section{Recent Developments}

25. After starting to recover from the global financial crisis, exports have stagnated since 2011. Despite growth in 2012 from Asia, the recession in Europe dragged down exports. MCD goods exports to the world declined by 7 percent in January - June 2013 relative to the same period in 2012. Non-petroleum imports from MCD countries have declined or remained unchanged since the second half of 2011. However, recent data show an increase in demand for non-petroleum goods, mainly driven by stronger imports from the euro area.

26. The MCD patterns mask substantial intra-regional variation. For example, the MENAP oil importers' non-oil exports to Europe fell by a third between mid-2011 and mid2012 on account of the recession there (Figure 4), and have not yet recovered to pre-Lehman levels despite a recent rise. CCA exports to Europe have stagnated since mid-2009, and strong growth to the BRICS in 2012 has been reversed (Figure 5), in large part due to falling sales to Russia, such that non-oil exports to the world have not reached pre-Lehman levels. The MENAP oil exporters experienced a steady rise in non-oil exports until the start of 2013.

Figure 4: Non-Oil Exports to Europe

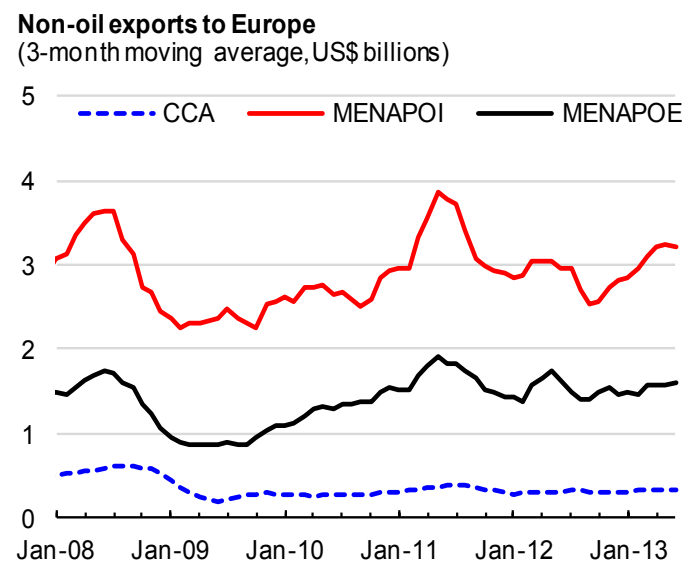

Figure 5: Non-Oil Exports to BRICS

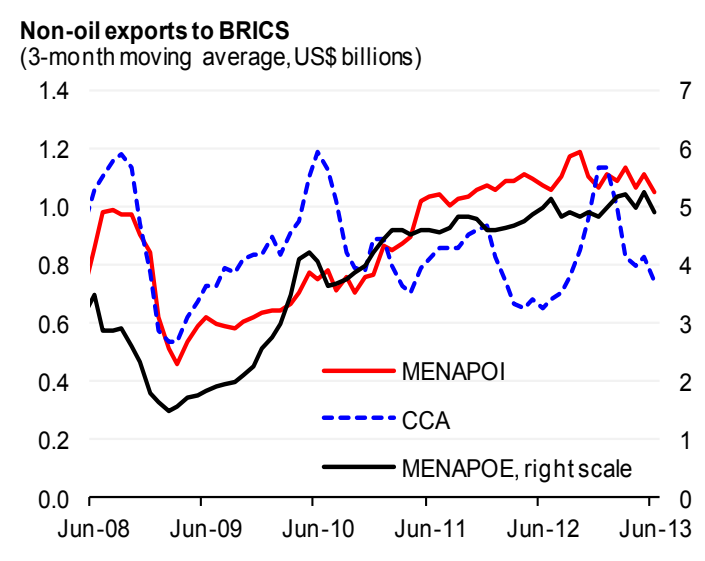

\section{REGRESSION RESULTS}

27. This section presents the regression results used for the simulations in the subsequent section. We have used a single set based on an Autoregressive Distributive Lag Specification for all goods, non-petroleum goods and for services. We use just the core set to keep the number of simulations manageable for the reader. However, we adopted a large number of alternative specifications and estimation methods that yielded robust results.

28. The ARDL representation is formally:

$$
X_{j, t}=c+\alpha X_{j, t-1}+\gamma_{1} Y_{j, t}+\gamma_{2} Y_{j, t-1}+\beta_{1} Y_{j, t}^{*}+\beta_{2} Y_{j, t-1}^{*}+\varepsilon_{j, t}
$$


Where $\mathrm{c}$ is a constant, $X_{j, t}$ is the $\log$ of exports by country $j$ in year $t, Y_{j, t}$ is the $\log$ of GDP in the exporter in year $t . Y_{j, t}^{*}$ is GDP in the rest of the world, which is the sum of all countries except the exporter $j$ weighted by the distance from the exporter. ${ }^{7} \beta_{1}$ is the short run elasticity of exports in country $j$ with respect to GDP in the rest of the world and is the main coefficient of interest. The long-run elasticity is $\left(\beta_{1}+\beta_{2}\right) /(1-\alpha) \cdot \varepsilon_{j, t}$ is a stochastic error term which has been interpreted as measurement error in the measurement of trade flows.

29. The estimated historical short-run elasticity for all goods is about 2. For all goods including oil, the short-run elasticity of a country's exports to trading partner GDP is estimated at 2.02 (column 1 of Table 2). Table 2 is based on ARDL least squares estimates including exporter fixed effects, and forms the basis for our simulations, but alternative estimation approaches are included in Table 3. The first column excludes country-specific effects and yields slightly higher short-run elasticities. GMM-based ${ }^{8}$ estimates due to Arellano and Bond (1991) and others in columns 2 and 3 are slightly lower than 2. Estimates in first differences, available on request, also yield estimates of about 2 .

30. Our estimates are broadly in line with others. Estimates of 2 are in line with unpublished estimates behind chapter IV of IMF (2010) on the trade response to financial crises. This is slightly higher than historical estimates of the aggregate world trade response to world GDP (1.77 since the 1960s) and aggregate exports from the MENA region alone (1.71 since the mid 1990s) in Freund (2009), but it is worth noting that such estimates are done using global or regional aggregates, which necessarily rely on very few observations and may be dominated by events in a few large countries.

31. The global trade response to global GDP may be rising and higher during substantial downturns. There is evidence that the elasticity has increased over time and that the trade response is greater during global downturns (Irwin, 2002; Freund, 2009). ${ }^{9}$ The 2009 collapse

\footnotetext{
${ }^{7}$ From an econometric point of view, an advantage of this is to generate more variation across exporters in trading partner GDP than one would get from the variation in world GDP over time, which does not vary across most exporters because most exporters are small. An alternative approach to aggregation would be to weight trading partner GDP by exports to that country, but the use of distance avoids the inclusion of export variables on the right hand side and is theoretically closer to the gravity model of bilateral trade. The relevance of distance is long-established for goods trade in gravity models but recent work suggests this applies for services too (Anderson, Milot \& Yotov, 2012). The use of distance also makes intuitive sense because, for aggregate exports, it matters whether the major shock to GDP is close to the exporter or far away. Gravity models offer multiple advantages but global bilateral services data are not easily available.

${ }^{8}$ The shape of our panel $(\mathrm{N} \approx 150 ; \mathrm{T} \approx 15)$ makes dynamic estimates susceptible to Nickell (1981) bias to the order of 5\%. GMM-based estimates can address this source of bias but their asymptotic validity relies on $\mathrm{N}$ being large relative to T, so they should be interpreted with some caution. We also exploit the estimator's ability to treat exporter GDP as endogenous or predetermined.

${ }^{9}$ Recent estimates indicate elasticities of about 3.5, but can draw on as few as 6 observations and should be treated with caution as a result.
} 
in world trade was four times that of world GDP, of which Bems et al (2010) attribute 70 percent to demand changes, which implies an elasticity of 2.8. A global trade response to a global contraction in demand is not necessarily the same as the simple average of country level responses, and the purpose of this paper is not to forecast world trade volumes.

Nonetheless, despite out focus on a region, a higher elasticity can be more appropriate if the trade response to GDP is now structurally higher than over the last 20 years, or if financial crises cause higher trade responses to GDP (in addition to other crisis-specific factors). ${ }^{10}$

Table 2: Preferred Export Elasticity Estimates

\begin{tabular}{lccc}
\hline & All goods & Non-oil & Services \\
\hline Lagged exports & $0.635^{* * *}$ & $0.271^{* * *}$ & $0.779^{* * *}$ \\
Exporter GDP & $(0.04)$ & $(0.05)$ & $(0.02)$ \\
& $0.955^{* * *}$ & $1.061^{*}$ & $1.096^{* * *}$ \\
Lagged Exporter GDP & $(0.28)$ & $(0.49)$ & $(0.23)$ \\
& $-0.663^{*}$ & -0.0629 & $-0.908^{* * *}$ \\
ROW GDP & $(0.31)$ & $(0.40)$ & $(0.22)$ \\
& $2.021^{* * *}$ & $3.297^{* * *}$ & $1.168^{*}$ \\
Lagged ROW GDP & $(0.37)$ & $(0.97)$ & $(0.50)$ \\
& $-1.661^{* * *}$ & $-2.525^{* *}$ & $-1.030^{*}$ \\
Constant & $(0.39)$ & $(0.90)$ & $(0.47)$ \\
& $1.875^{*}$ & 0.76 & $-1.871^{*}$ \\
Long Run & $(0.85)$ & $(4.12)$ & $(0.78)$ \\
& 0.986 & 1.060 & 0.625 \\
Observations & $(0.47)$ & $(0.53)$ & $(0.63)$ \\
Adjusted R ${ }^{2}$ & 2089 & 1573 & 1690 \\
Significant at ${ }^{* * *} 0.1 \%{ }^{* *} 1 \%,{ }^{*} 5 \% ;$ ROW $=$ distance weighted rest of the world GDP; & 0.96 \\
standard errors clustered by exporter are shown in parenthesis; all variables in \\
logs. Exporter fixed effects not shown. Estimation by least squares.
\end{tabular}

32. The short-run elasticity is higher for non-petroleum exports than overall exports. Our estimate for non-petroleum goods exports (non-oil for short) is 3.3 (column 2 of Table 2). The one standard error confidence bands of this estimate are at approximately 2.3 and 4.3.

Alternative ARDL estimates in Table 3 vary from 3.1 to 4.2, while first-differenced estimates available on request are slightly lower. Petroleum products are a kind of intermediate input, so this relatively high elasticity is consistent with the findings in Bems et al (2010) that intermediates were less sensitive to GDP than final goods. ${ }^{11}$ It is also consistent with the view that it is in many cases easy to divert oil exports to alternate markets, making oil a globally traded commodity. ${ }^{12}$ This implies that gravity in a formal sense is not an appropriate way to

\footnotetext{
${ }^{10}$ There is evidence that crisis episodes are associated with drops in trade even after controlling for drops in GDP (IMF, 2010).

${ }^{11}$ However, evidence is mixed. See for example Levchenko, Lewis \& Tesar (2009), where vertically integrated sectors had bigger falls and Altomonte \& Ottaviano (2009), where global supply chains were resilient.

${ }^{12}$ It is not feasible to do regressions only for oil exports with this type of data due to a lack of observations.
} 
assess oil exports and that shocks in particular regions are only important for a particular oil exporter only insofar as they affect global demand.

33. Service exports are less sensitive to GDP. The short-run elasticity of service exports to trading partner GDP is 1.17 (column 3 of Table 2), with a range between 0.94 and 1.37 (Table $3)$. This is consistent with the observation that services trade did not collapse nearly as much as goods trade during 2009 (Martins \& Araujo, 2009; Borchert \& Mattoo, 2009). ${ }^{13}$

Supplementary regressions available on request show that services value-added changes by less than one-for-one with GDP while industrial value added changes by more, which is consistent with Bems et al (2010).

Table 3: Alternative ARDL Estimates

\begin{tabular}{|c|c|c|c|c|c|c|c|c|c|}
\hline & \multicolumn{3}{|c|}{ All goods } & \multicolumn{3}{|c|}{ Non-oil } & \multicolumn{3}{|c|}{ Services } \\
\hline Lagged Exports & $0.946^{* * *}$ & $0.661^{* * *}$ & $0.672^{\star * *}$ & $0.792^{* * *}$ & $0.272^{\star \star *}$ & $0.296^{* * *}$ & $0.926^{* * *}$ & $0.833^{\star \star \star}$ & $0.840^{* * *}$ \\
\hline Exporter GDP & $0.876^{* * *}$ & $1.518^{* \star *}$ & $1.307^{\star \star \star}$ & $0.978^{*}$ & 0.908 & 0.8 & $1.191^{* * *}$ & $1.322^{\star * *}$ & $1.689^{* * *}$ \\
\hline Lagged Exporter GDP & $-0.824^{* * *}$ & $-1.092^{* * *}$ & $-0.912^{* * *}$ & $-0.751+$ & -0.115 & -0.0321 & $-1.123^{* * *}$ & $-1.043^{* * *}$ & $-1.419^{* * *}$ \\
\hline ROW GDP & $2.239^{* * *}$ & $1.671^{* * *}$ & $1.841^{* * *}$ & $3.051^{* * *}$ & $4.156^{* \star *}$ & $3.852^{* * *}$ & $1.367^{\star}$ & $1.190^{* *}$ & $0.937^{\star}$ \\
\hline Lagged ROW GDP & $-2.167^{* * *}$ & $-1.568^{* * *}$ & $-1.699^{* * *}$ & $-2.627^{* *}$ & $-3.068^{* * *}$ & $-2.925^{* *}$ & $-1.208^{*}$ & $-1.166^{* * *}$ & $-0.899^{*}$ \\
\hline Constant & -0.0135 & $3.570^{* * *}$ & $3.062^{* * *}$ & $-1.735^{*}$ & -1.734 & -0.345 & $-1.937^{* *}$ & $-1.107^{\star}$ & $-1.241^{*}$ \\
\hline Long Run & 1.35 & 0.31 & 0.43 & 2.041 & 1.495 & 1.318 & 2.155 & 0.145 & 0.241 \\
\hline $\mathrm{N}$ & 2089 & 2089 & 2089 & 1573 & 1573 & 1573 & 1690 & 1690 & 1690 \\
\hline Exporter-specific effects? & $\mathrm{N}$ & \multicolumn{2}{|c|}{ First differences } & $\mathrm{N}$ & \multicolumn{2}{|c|}{ First differences } & $\mathrm{N}$ & \multicolumn{2}{|c|}{ First differences } \\
\hline GMM? & $\mathrm{N}$ & Endogenous & Predetermined & $\mathrm{N}$ & Endogenous & Predetermined & $\mathrm{N}$ & Endogenous & Predetermined \\
\hline
\end{tabular}
Significant at ${ }^{* *} 0.1 \%,{ }^{* *} 1 \%,{ }^{*} 5 \% ;$ ROW $=$ distance weighted rest of the world GDP; standard errors clustered by exporter; all variables in logs.

34. Long-run elasticities approach unity for goods exports. Our ARDL specification permits the calculation of long run elasticities. Consistent with the theory underlying gravity models and the vast majority of empirical estimates, the elasticity is about unity for all goods or non-petroleum exports in our preferred specifications. This can be reconciled with the higher short-run elasticities because, in the long run, all components of aggregate demand should increase at the same rate, which rules out composition effects, any potential effects of intermediate goods, and temporary effects due to insufficient trade finance. Such models are arguably better suited to goods, which may explain why service exports have a long-run elasticity that is less than unity.

35. Durables account for a large component of the exports response to GDP, but we use estimates of the export response to overall GDP. One of the explanations for why short-run elasticities exceed unity is the so-called composition effect. If these are at play, then

\footnotetext{
${ }^{13}$ A few papers have attempted to estimate service trade elasticities, which tend to be high but are unsatisfactory for a number of reasons including problematic specification of trading partner GDP.
} 
predictions of the components of demand can be more useful for projecting trade effects. ${ }^{14}$ Subsequent analysis indicates an elasticity of exports with respect to durables demand alone in trading partners of about a quarter (all goods) to almost a half (non-petroleum), which is large given that this component is only about a tenth of overall demand and important given that durables demand is much more volatile than the rest of GDP. However, results available on request of a separate analysis of durables and the rest of GDP yields implied output elasticities that do not exceed those presented in Table 2. With the caveat that data on durables demand is relatively limited, the analysis implies that, although demand subcomponents can explain high elasticities of exports with respect to output, doing regressions on aggregate GDP does not lead to systematic underestimates. Given that it is easier to find projections of the impact of a Euro area escalation on GDP than on demand subcomponents, we choose to use the GDP elasticities.

36. Elasticities are not systematically different in the MENAP or CCA and do not vary across importing regions. In the short run, one might expect that a country or region's export bundle may be more or less sensitive to global demand than the world average. We attempted a number of specifications to investigate whether some sub-regions have different export elasticities. We did not find robust statistically significant evidence of this for the MENAP, the CCA or smaller subgroups. Similarly, we found no evidence of differences in elasticities across importers. In other words, the trade response to GDP was not systematically higher for particular importing regions (like Europe or Asia). Furthermore, we did not find evidence pertaining to particular importer-exporter pairs (for example Maghreb exports to Europe or GCC exports to Asia). We note that this is consistent with the theory: while there are good reasons to expect variations in levels across countries, it is harder to find robust theoretical reasons for elasticities to differ.

\section{Simulations}

37. This section presents simulations of the implications of actual or potential global GDP shocks on non-oil exports from the region based on estimates in Table 2. One interpretation of the regression results is that an evenly-distributed fall in global GDP of 1 percent would reduce MCD non-petroleum exports by 3.3 percent in the short run and 1.06 percent in the long run. However, the geographical distribution of a global contraction is important; for exporters to Europe, a 1 percent fall in aggregate global GDP matters more if it is concentrated in Europe. This section takes into account the uneven distribution of GDP growth as well as the unequal export exposures to each region to estimate export implications from hypothetical GDP shock scenarios and actual revisions to the growth outlook. In

\footnotetext{
${ }^{14}$ This would be especially the case if the region's main trading partners tended to experience greater asymmetries in the subcomponents of demand, for example European changes in durables demand being a bigger multiple of changes in GDP than the rest of the world. However, we did not find this to be the case.
} 
particular, we consider two scenarios for weaker euro area growth, a slowdown in the BRICS, and revisions to global growth projections for 2011-14.

38. We focus on non-oil exports because these are more appropriately captured by the gravity model and because geographical data are available. Oil exports are less dependent on shocks to particular countries or regions because oil is generally traded on global markets. Furthermore, much of the adjustment comes in the form of oil prices and most countries produce at or near capacity. While one or more major producers would likely scale back output to keep oil markets in balance, (IMF, 2012b) such a decision is not adequately modeled in a gravity framework. Our discussion of services exports is limited because bilateral data are not available.

39. We combine the vector of contractions in key trading partner GDP with the share of exports from each MCD country to that trading partner region. For the downside scenarios, these regions are Europe, Asia, BRICS, the U.S, and the rest of the World. ${ }^{15}$ Formally, the short-run impact is:

$$
\tilde{X}_{j, t}^{S R}=\beta_{1}^{g} \sum S_{j k}^{g} \tilde{Y}_{k, t}
$$

where $\tilde{X}_{j, t}^{S R}$ is the percentage change in exports from exporter $j$ at time $t$ experienced for good $g$. $\beta_{1}^{g}$ is the short run coefficient for good $\mathrm{g}$ (eg non-oil exports), $s_{j k}^{g}$ is the share of $j$ 's exports of good $g$ exported to destination $k$, and $\tilde{Y}_{k, t}$ is the percentage change in GDP (the revision or shock relative to the baseline) in export destination $k$. For brevity, we aggregate country-level export responses into relevant MCD sub-regions. We will calculate these so-called short-run coefficients based on $\beta_{1}^{g}$ for up to two years cumulatively in the scenarios and for up to four years for the actual downward revision to growth prospects. These are best interpreted as an approximation of the cumulative initial impacts of the shocks experienced over the period, but they will dissipate.

As a result, the long-run analogue is:

$$
\tilde{X}_{j, t}^{L R}=\frac{\beta_{1}^{g}+\beta_{2}^{g}}{1-\alpha^{g}} \sum s_{j k}^{g} \tilde{Y}_{k, t},
$$

\footnotetext{
${ }^{15}$ Trade exposures are based on all countries in the world, subject to data availability. GDP shocks to regions are approximated by shocks to GDP in a subset of countries in the IMF's global macroeconomic models. In particular, Europe consists of Austria, Belgium, Finland, France, Germany, Greece, Ireland, Italy, Netherlands, Portugal, Spain, and the United Kingdom. The BRICS are fully represented by Brazil, Russia, India, China, and South Africa. Asia is represented by Indonesia, Japan and Korea. Other countries are Argentina, Canada, Australia, Mexico and Turkey. No MCD countries are included here.
} 
where $\beta_{1}^{g}$ as before is the coefficient on the contemporaneous trading-partner output term, $\beta_{2}^{g}$ is the coefficient on lagged trading-partner output, and $\alpha^{g}$ is the coefficient on lagged exports. Although we do not simulate the full path of export impacts beyond four years, these impacts should be interpreted as the eventual long-run impact of the shocks experienced during this period.

40. Our reduced form approach complements structural approaches based on input-output linkages. We have argued that indirect effects matter because a fall in GDP in Europe would translate to falls in GDP and hence demand in other parts of the world. Our method for dealing with this is simple and based on a reduced form relationship with GDP. An analogous argument is that a collapse in demand in Europe not only leads to a fall in demand for final goods produced in the Middle East and Central Asia, but also for final goods produced elsewhere, which means demand for intermediate products produced in the Middle East and Central Asia falls. For example, European demand for final goods assembled in Asia leads to a fall in Asian demand for intermediates supplied by the Middle East. Our approach is complementary to the structural approach based on input-output tables in Johnson \& Noguera (2012) and Bems and others (2010). Chalk and others (2012) estimate that the elasticity of Chinese imports with respect to exports is about a half, which is consistent with the import content of exports derived from input-output tables.

41. Sub-regional variation is determined by export shares. Differences between subgroups within MCD are not based on different elasticities because, as discussed earlier, we did not find robust evidence of differences in elasticities. As a result, by construction, differences in export impacts across MCD countries are based solely on the differences in the geographical distribution of exports.

\section{A. Euro Area Shocks}

42. Waning confidence, lower investments and heightened concerns about fiscal sustainability in the euro area could lead to persistently slower growth in the currency union as well as the rest of Europe and the world. According to EUROMOD, an IMF model of the global economy, Europe's growth could fall by $1 / 2$ percent per year over 5 years due to rising risk premia and the ensuing fiscal tightening as well as lower confidence and the resultant weaker private investment. European GDP would be 1.1 percent lower than the baseline in the second year such that the cumulative loss over 2 years would be 1.7 percent. In this case, most of the GDP effects outside of Europe are small so that the cumulative global GDP loss over two years would be $1 / 2$ percent (Table 4). For further details, see the April 2013 World Economic Outlook. 
Table 4: Weak Growth in Europe Scenario

\begin{tabular}{|c|c|c|c|c|c|c|c|c|c|}
\hline & \multicolumn{3}{|c|}{ Direct effect (Europe only) } & \multicolumn{3}{|c|}{ Indirect effect (outside of Europe) } & \multicolumn{3}{|c|}{ Total (World) } \\
\hline & Year 1 & Year 2 & Cumulative & Year 1 & Year 2 & Cumulative & Year 1 & Year 2 & Cumulative \\
\hline GDP shock $^{1}$ & -0.5 & -1.1 & -1.7 & -0.1 & -0.2 & -0.2 & -0.1 & -0.4 & -0.5 \\
\hline \multicolumn{10}{|l|}{ Short run } \\
\hline MENAP & -0.4 & -0.9 & -1.3 & -0.1 & -0.1 & -0.2 & -0.5 & -1.0 & -1.5 \\
\hline MENAP oil importers & -0.6 & -1.5 & -2.1 & -0.1 & -0.2 & -0.2 & -0.7 & -1.7 & -2.4 \\
\hline MENAP oil exporters & -0.3 & -0.6 & -0.9 & -0.1 & -0.2 & -0.2 & -0.3 & -0.8 & -1.1 \\
\hline GCC & -0.1 & -0.3 & -0.5 & -0.1 & -0.2 & -0.3 & -0.2 & -0.5 & -0.8 \\
\hline Maghreb & -1.3 & -3.1 & -4.4 & 0.0 & -0.1 & -0.1 & -1.4 & -3.1 & -4.5 \\
\hline Mashreq & -0.6 & -1.5 & -2.1 & 0.0 & -0.1 & -0.2 & -0.7 & -1.6 & -2.3 \\
\hline CCA & -0.5 & -1.0 & -1.5 & -0.1 & -0.2 & -0.3 & -0.5 & -1.3 & -1.8 \\
\hline CCA oil importers & -0.4 & -1.0 & -1.5 & -0.1 & -0.2 & -0.2 & -0.5 & -1.2 & -1.7 \\
\hline CCA oil exporters & -0.5 & -1.0 & -1.5 & -0.1 & -0.2 & -0.3 & -0.5 & -1.3 & -1.8 \\
\hline \multicolumn{10}{|l|}{ Long run } \\
\hline MENAP & -0.1 & -0.3 & -0.4 & 0.0 & 0.0 & -0.1 & -0.1 & -0.3 & -0.5 \\
\hline MENAP oil importers & -0.2 & -0.5 & -0.7 & 0.0 & -0.1 & -0.1 & -0.2 & -0.5 & -0.8 \\
\hline MENAP oil exporters & -0.1 & -0.2 & -0.3 & 0.0 & -0.1 & -0.1 & -0.1 & -0.3 & -0.4 \\
\hline GCC & 0.0 & -0.1 & -0.2 & 0.0 & -0.1 & -0.1 & -0.1 & -0.2 & -0.2 \\
\hline Maghreb & -0.4 & -1.0 & -1.4 & 0.0 & 0.0 & 0.0 & -0.4 & -1.0 & -1.4 \\
\hline Mashreq & -0.2 & -0.5 & -0.7 & 0.0 & 0.0 & -0.1 & -0.2 & -0.5 & -0.7 \\
\hline CCA & -0.1 & -0.3 & -0.5 & 0.0 & -0.1 & -0.1 & -0.2 & -0.4 & -0.6 \\
\hline CCA oil importers & -0.1 & -0.3 & -0.5 & 0.0 & -0.1 & -0.1 & -0.2 & -0.4 & -0.5 \\
\hline CCA oil exporters & -0.1 & -0.3 & -0.5 & 0.0 & -0.1 & -0.1 & -0.2 & -0.4 & -0.6 \\
\hline
\end{tabular}

${ }^{1}$ As presented in the April 2013 World Economic Outlook using EUROMOD, an IMF model of the global economy.

43. Table 4 presents short-run and long-run estimates of the impact on non-oil exports. The MENAP countries are grouped into oil importers and oil exporters or alternatively as Maghreb, Mashreq and GCC non-exhaustive subsets. Similarly, the CCA countries are aggregated into the CCA oil exporters and the CCA oil importers.

44. A mild shock in Europe implies modest effects, except in the Maghreb. In the MENAP region, the short-run estimates imply non-oil exports would be $1 / 2$ percent lower than the baseline in the first year and 1 percent lower in the second year; equivalently, there would be an annual export growth shock of $1 / 2$ percent and a cumulative export loss of $1 \frac{1}{2}$ percent over two years. Of this $1 \frac{1}{2}$ percent, 1.3 percent would be direct losses to Europe, while the indirect loss to the rest of the world would be only 0.2 percent due to the small GDP shock outside of Europe. In the Maghreb, large direct exposures to Europe would result in an export loss of 1.4 percent in the first year and a cumulative $4 \frac{1}{2}$ percent over two years. In other MENAP countries, export losses could be considerably smaller. In the CCA countries, the cumulative loss is estimated to be 1.8 percent over $2 .{ }^{16}$ The estimated long-run impact is generally small.

45. Estimates are subject to parameter uncertainty. The figures in Table 4 are based on a preferred coefficient estimate in Table 2 of 3.3. Given the standard error of the regression estimate, the confidence interval one standard error above the estimate for the MENAP

\footnotetext{
${ }^{16}$ The effects are similar in the oil importers and oil exporters despite higher CCA oil importer exposures to Europe because of the large exposure of Kazakhstan, an oil exporter, to Europe and because Kazakhstan has a large PPP weight in the group.
} 
cumulative impact is at -1.9 percent while the lower confidence band is at -1 percent. Similarly, the Maghreb range is -3.1 to -5.8 percent and the CCA range is -1.3 to -2.3 percent.

46. Stalled or incomplete delivery of policy commitments could lead to the re-emergence of financial stress in the euro area, resulting in a substantial fall in GDP. Although the ECB's Long Term Refinancing Operation and Outright Monetary Transactions program as well as government promises of fiscal adjustment and structural reform have reduced market doubts, risks of an acute crisis have not dissipated. Social tensions and adjustment fatigue could renew doubts regarding the euro area periphery and/or deeper integration. The sovereign and banking stress that might arise as a result is modeled using the IMF's Global Integrated Monetary and Fiscal Model and described in the October 2012 World Economic Outlook. In the model, the ensuing growth shock would be acute. In Europe, GDP is 2.8 percent lower than the baseline in the first year. The GDP growth shock is limited to one year such that output in the second year is also 2.8 percent below baseline and the cumulative output loss is 5.6 percent over two years. With similar dynamics, global GDP falls by 1.1 percent in the first year for a cumulative output loss of 2.2 percent over two years.

47. The more acute euro area shock scenario implies more severe non-oil export losses. For the MENAP countries as a whole, cumulative export losses over two years could be about 6 percent in the first year alone, but there is substantial variation (Table 5 and Figure 6 ). In the Maghreb, the first-year impact is estimated to be $-71 \frac{1}{2}$ percent and the cumulative impact could be more than -15 percent, almost exclusively from Europe. Accounting for confidence bands, the cumulative loss ranges from 11 to 20 percent. For the GCC, the estimated cumulative fall is about $3 \frac{1}{2}$ percent, of which less than half is directly from Europe. Estimates for the Mashreq and the CCA are in between. 
Table 5: Re-emergence of Financial Stress in Euro Area Scenario

\begin{tabular}{|c|c|c|c|c|c|c|c|c|c|}
\hline & \multicolumn{3}{|c|}{ Direct effect (Europe only) } & \multicolumn{3}{|c|}{ Indirect effect (outside of Europe) } & \multicolumn{3}{|c|}{ Total (World) } \\
\hline & Year 1 & Year 2 & Cumulative & Year 1 & Year 2 & Cumulative & Year 1 & Year 2 & Cumulative \\
\hline GDP shock $^{1}$ & -2.8 & -2.8 & -5.6 & -0.7 & -0.7 & -1.4 & -1.1 & -1.1 & -2.2 \\
\hline \multicolumn{10}{|l|}{ Short run } \\
\hline MENAP & -2.2 & -2.2 & -4.4 & -0.8 & -0.7 & -1.5 & -3.0 & -2.9 & -6.0 \\
\hline MENAP oil importers & -3.6 & -3.6 & -7.2 & -0.8 & -0.7 & -1.5 & -4.4 & -4.3 & -8.8 \\
\hline MENAP oil exporters & -1.5 & -1.5 & -3.1 & -0.8 & -0.8 & -1.5 & -2.3 & -2.3 & -4.6 \\
\hline GCC & -0.8 & -0.8 & -1.6 & -1.0 & -1.0 & -2.0 & -1.8 & -1.8 & -3.6 \\
\hline Maghreb & -7.5 & -7.4 & -14.8 & -0.3 & -0.3 & -0.5 & -7.7 & -7.6 & -15.4 \\
\hline Mashreq & -3.6 & -3.5 & -7.1 & -0.6 & -0.5 & -1.1 & -4.1 & -4.1 & -8.2 \\
\hline CCA & -2.5 & -2.5 & -5.1 & -1.2 & -1.0 & -2.2 & -3.7 & -3.6 & -7.3 \\
\hline CCA oil importers & -2.5 & -2.4 & -4.9 & -0.8 & -0.7 & -1.6 & -3.3 & -3.2 & -6.5 \\
\hline CCA oil exporters & -2.6 & -2.5 & -5.1 & -1.2 & -1.1 & -2.3 & -3.8 & -3.6 & -7.4 \\
\hline \multicolumn{10}{|l|}{ Long run } \\
\hline MENAP & -0.7 & -0.7 & -1.4 & -0.3 & -0.2 & -0.5 & -1.0 & -0.9 & -1.9 \\
\hline MENAP oil importers & -1.2 & -1.2 & -2.3 & -0.3 & -0.2 & -0.5 & -1.4 & -1.4 & -2.8 \\
\hline MENAP oil exporters & -0.5 & -0.5 & -1.0 & -0.3 & -0.2 & -0.5 & -0.7 & -0.7 & -1.5 \\
\hline GCC & -0.3 & -0.3 & -0.5 & -0.3 & -0.3 & -0.6 & -0.6 & -0.6 & -1.1 \\
\hline Maghreb & -2.4 & -2.4 & -4.8 & -0.1 & -0.1 & -0.2 & -2.5 & -2.4 & -4.9 \\
\hline Mashreq & -1.1 & -1.1 & -2.3 & -0.2 & -0.2 & -0.4 & -1.3 & -1.3 & -2.6 \\
\hline $\mathrm{CCA}$ & -0.8 & -0.8 & -1.6 & -0.4 & -0.3 & -0.7 & -1.2 & -1.1 & -2.3 \\
\hline CCA oil importers & -0.8 & -0.8 & -1.6 & -0.3 & -0.2 & -0.5 & -1.1 & -1.0 & -2.1 \\
\hline CCA oil exporters & -0.8 & -0.8 & -1.6 & -0.4 & -0.4 & -0.7 & -1.2 & -1.2 & -2.4 \\
\hline
\end{tabular}

${ }^{1}$ As presented in the October 2012 World Economic Outlook using the IMF's Global Integrated Monetary and Fiscal Model (GIMF).

Figure 6: Two-year Cumulative Non-Oil Export Impact of Euro Area Financial Stress, percent

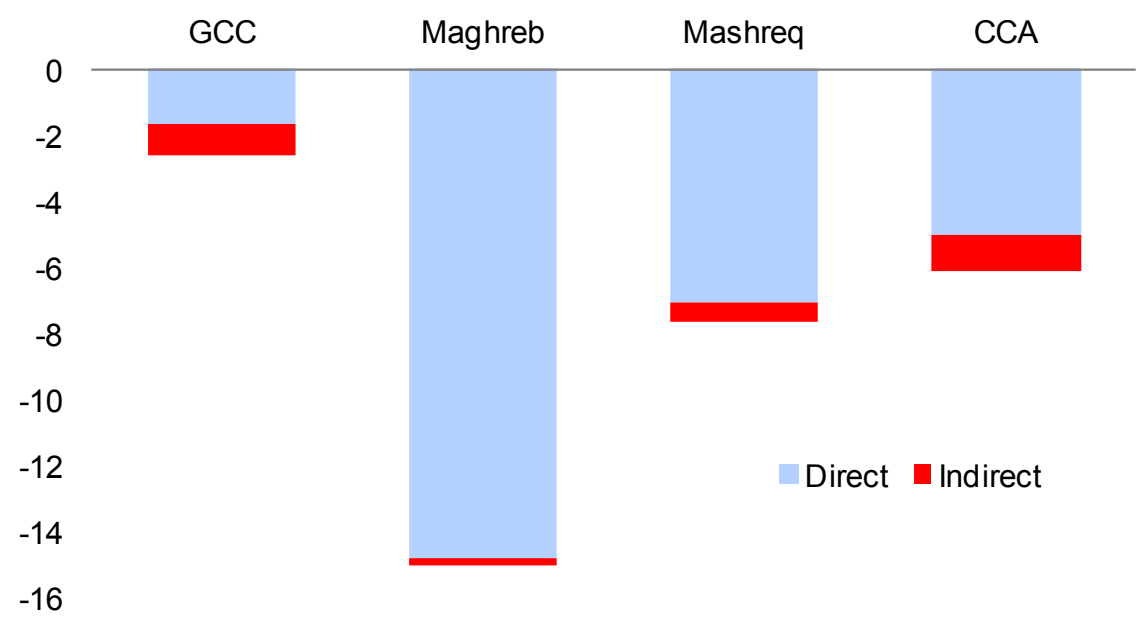

48. The two euro area scenarios imply a short-run elasticity of non-oil exports with respect to European GDP of approximately unity. Elasticities vary slightly across scenarios because the export responses are not perfectly linear. Nonetheless, the non-oil export losses and European GDP losses can be compared to assess approximate elasticities that may be a useful rule of thumb. These indicate an elasticity of 0.9-1 for the MENAP countries (including an elasticity of 23/4 in the Maghreb) and 1.1-1.3 in the CCA. Especially for the Mashreq, these could be adjusted upwards to account for intra-MCD trade.

49. Services and oil export values would also fall. We have noted that a full analysis of services exports is not possible due to a lack of bilateral services export data, but it can be instructive to assume that export shares to Europe are the same for services and non- 
petroleum goods. ${ }^{17}$ Doing so yields a first-year impact of $-1 \frac{1}{4}$ percent for the CCA and 1 percent for the MENAP. Similarly, if we assume Maghreb service export exposures to Europe are as high as they are for non-oil goods, the estimates first-year impact would be $23 / 4$ percent. The GIMF model of this scenario also estimates that oil price would fall about 10 percent in the first year, but this would depend on the extent of output adjustment, if any, by major oil producers. In either case, oil export values would fall.

\section{B. Emerging Market Shock}

50. A sharp slowdown in major emerging market economies is an important risk. Emerging market economies have been growing slower than in the recent past and concerns of an abrupt slowdown in one or more major emerging markets have escalated. Private investment has repeatedly surprised on the downside and the April 2013 World Economic Outlook (IMF, 2013c) discusses the implications of investment being 10 percent below forecast in the BRICS countries and being accompanied by capital outflows from other emerging markets. This would reduce BRICS output by $3^{1 / 2}$ percent in the first year and by more than 4 percent in the second year - the size of the shock is similar in each of the countries. Due to spillovers, the GDP loss in non-BRICS regions (including Europe) would be approximately 1 percent in the first year (Table 6).

51. CCA countries would be most affected given large direct exposures to Russia and China. In the CCA oil exporters, non-oil exports would fall by 6 percent in the first year (Table 6), chiefly because of direct exposures to the BRICS, which in turn are dominated by Russia and China. The cumulative loss over two years is estimated to be about 13 percent. For the CCA oil importers, the indirect effects are equally large, but exposures to China and hence the BRICS are lower, resulting in an overall cumulative effect of -9 percent. Allowing for the uncertainty surrounding the regression estimate, the range for the cumulative CCA loss is roughly 9-16 percent. For the MENAP countries, the estimated cumulative loss is about 6 percent, with a range of approximately 4-8 percent. The indirect effects are as about as big as the indirect effects because spillovers from the BRICS to Europe would reduce exports to Europe as well as to the BRICS (Table 6 and Figure 7).

\footnotetext{
${ }^{17}$ As previously noted, there is emerging evidence that bilateral patterns of services trade can be explained by gravity models; in particular GDP and distance (Anderson, Milot \& Yotov, 2012).
} 
Table 6: BRICS Slowdown Scenario

\begin{tabular}{|c|c|c|c|c|c|c|c|c|c|}
\hline & \multicolumn{3}{|c|}{ Direct effect (BRICS only) } & \multicolumn{3}{|c|}{ Indirect effect (other than BRICS) } & \multicolumn{3}{|c|}{ Total (World) } \\
\hline & Year 1 & Year 2 & Cumulative & Year 1 & Year 2 & Cumulative & Year 1 & Year 2 & Cumulative \\
\hline GDP shock $^{1}$ & -3.5 & -4.1 & -7.6 & -1.1 & -1.2 & -2.4 & -2.0 & -2.3 & -4.2 \\
\hline \multicolumn{10}{|l|}{ Short run } \\
\hline MENAP & -1.3 & -1.6 & -2.9 & -1.6 & -1.7 & -3.3 & -2.9 & -3.3 & -6.2 \\
\hline MENAP oil importers & -0.9 & -1.0 & -1.9 & -2.2 & -2.4 & -4.6 & -3.1 & -3.5 & -6.6 \\
\hline MENAP oil exporters & -1.6 & -1.8 & -3.4 & -1.3 & -1.4 & -2.6 & -2.8 & -3.2 & -6.0 \\
\hline GCC & -1.8 & -2.1 & -3.9 & -1.3 & -1.4 & -2.6 & -3.0 & -3.5 & -6.5 \\
\hline Maghreb & -0.5 & -0.6 & -1.1 & -2.9 & -3.2 & -6.1 & -3.4 & -3.8 & -7.2 \\
\hline Mashreq & -0.6 & -0.7 & -1.3 & -1.9 & -2.1 & -4.0 & -2.5 & -2.8 & -5.4 \\
\hline $\mathrm{CCA}$ & -4.6 & -5.4 & -9.9 & -1.2 & -1.3 & -2.5 & -5.7 & -6.7 & -12.4 \\
\hline CCA oil importers & -2.9 & -3.4 & -6.3 & -1.2 & -1.3 & -2.5 & -4.1 & -4.7 & -8.8 \\
\hline CCA oil exporters & -4.9 & -5.7 & -10.6 & -1.2 & -1.3 & -2.5 & -6.0 & -7.0 & -13.1 \\
\hline \multicolumn{10}{|l|}{ Long run } \\
\hline MENAP & -0.4 & -0.5 & -0.9 & -0.5 & -0.6 & -1.1 & -0.9 & -1.1 & -2.0 \\
\hline MENAP oil importers & -0.3 & -0.3 & -0.6 & -0.7 & -0.8 & -1.5 & -1.0 & -1.1 & -2.1 \\
\hline MENAP oil exporters & -0.5 & -0.6 & -1.1 & -0.4 & -0.4 & -0.8 & -0.9 & -1.0 & -1.9 \\
\hline GCC & -0.6 & -0.7 & -1.2 & -0.4 & -0.4 & -0.8 & -1.0 & -1.1 & -2.1 \\
\hline Maghreb & -0.2 & -0.2 & -0.4 & -0.9 & -1.0 & -2.0 & -1.1 & -1.2 & -2.3 \\
\hline Mashreq & -0.2 & -0.2 & -0.4 & -0.6 & -0.7 & -1.3 & -0.8 & -0.9 & -1.7 \\
\hline $\mathrm{CCA}$ & -1.5 & -1.7 & -3.2 & -0.4 & -0.4 & -0.8 & -1.8 & -2.1 & -4.0 \\
\hline CCA oil importers & -0.9 & -1.1 & -2.0 & -0.4 & -0.4 & -0.8 & -1.3 & -1.5 & -2.8 \\
\hline CCA oil exporters & -1.6 & -1.8 & -3.4 & -0.4 & -0.4 & -0.8 & -1.9 & -2.3 & -4.2 \\
\hline
\end{tabular}

${ }^{1}$ As presented in April 2013 World Economic Outlook using EUROMOD, an IMF model of the global economy.

52. The implied elasticities indicate higher exposures to the BRICS for the CCA countries. The short-run elasticity for CCA countries is approximately $1 \frac{1}{2}$ and the long-run elasticity is approximately $1 / 3$, mainly because of the CCA oil exporters. These elasticities are somewhat higher than for the European shocks due to large direct exposures to Russia and China. For the MENAP countries, the short-run elasticity of about $3 / 4$ and the long-run elasticity of about $1 / 4$ are in equal parts attributable to direct BRICS and indirect (mostly Europe) effects. These indirect exposures make the elasticity with respect to a BRICS shock only slightly lower than the elasticity with respect to a shock originating in Europe.

Figure 7: Two-year Cumulative Non-Oil Export Impact of BRICS shock, percent

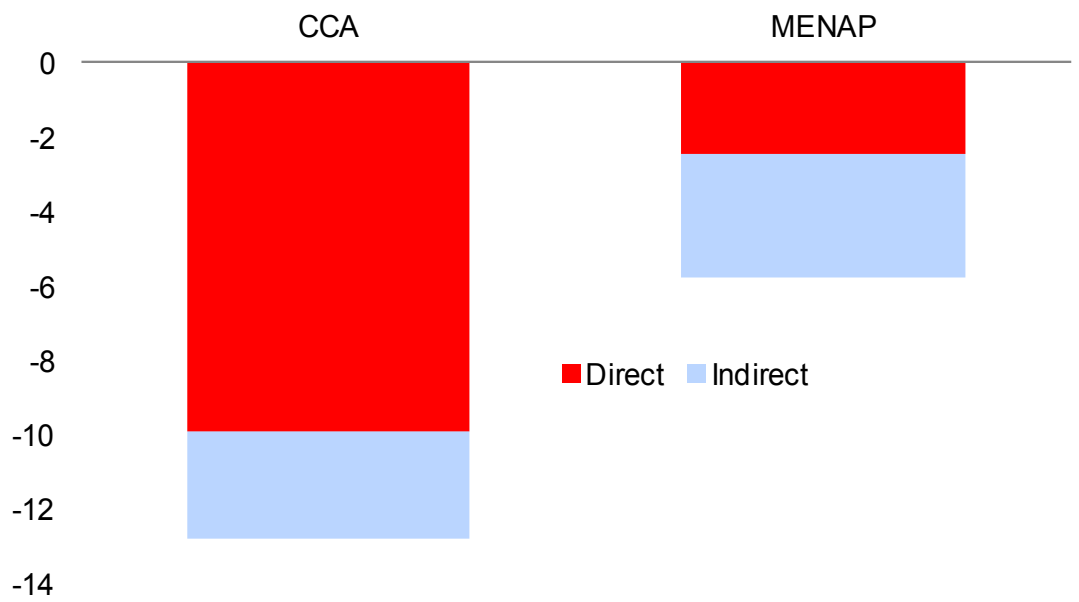


53. Oil revenue losses could be substantial and services exports would also fall. The EUROMOD analysis suggests oil prices could fall by 20 percent in the first year, in large part to the energy-intensity of China's GDP, depending on the nature of any supply response.

While most countries produce at full capacity, a number of OPEC members could scale back oil production, as they did in 2009. Services would also be affected. Based on a uniform global GDP loss, services exports could fall by $2 \frac{1}{3}$ percent in the first year. Assuming the same geographical exposures as non-oil goods exports, the services impact would be roughly the same for many MENAP countries but would be about 4 percent for the CCA countries.

\section{Downward Revisions of the Global Outlook}

54. Global growth performance has been weaker than anticipated. In the October 2013 World Economic Outlook, actual growth in 2011-2012 as well as forecasts for 2013-2014 were substantially lower than forecasts for 2011-2014 in the October 2010 Outlook. Global GDP growth estimates/projections were on average 1 percent per annum lower in the more recent edition, which implies a cumulative GDP loss of 91/2 percent over 2011-2014 (Table 7). We saw in section II that the MCD region's growth in non-oil exports came to a standstill in 2011.

55. There is substantial variation in the change in outlook across the world. Contributing to the downward global revision are relatively large adjustments in Europe (a cumulative GDP loss of 101/2 percent for 2011-14 despite an upward revision for 2011) and the BRICS (2 percent growth per annum on average and a cumulative GDP loss of $16 \frac{1}{2}$ percent). Other downward revisions were much smaller and there were also upward revisions. Having examined hypothetical downside scenarios, what do the actual downward revisions in realized and forecast growth performance imply for MCD exports?

56. Cumulative non-petroleum losses are a third of annual exports in the CCA and almost a fifth in the MENAP. For the CCA countries, the estimated short-run loss of exports in 20112014 is 32.7 percent of a year's exports (Table 7), or 4 months' exports. This translates roughly to an average loss of export growth of 3 percent in each of the four years. Allowing for parameter uncertainty in the regressions, the short-run loss ranges from 23 to 43 percent. Most of the CCA loss is due to slower growth in emerging markets. Barring any further downward revisions, the long-run loss would be 7 percent. For the MENAP countries, the cumulative short-run loss is about 19 percent, with a range of 13-24 percent. In the Maghreb, a cumulative loss is of a similar magnitude to the CCA, but is mostly attributable to the downward revisions in Europe. 
Table 7: Implications of Revisions to Global Growth

\begin{tabular}{lccc}
\hline & $\begin{array}{c}\text { Europe } \\
\text { Cumulative loss, }\end{array}$ & 2011-2014 \\
\hline GDP loss ${ }^{1}$ & -10.4 & -16.6 & -9.4 \\
\hline Short run & -8.2 & -6.3 & -18.7 \\
MENAP & -13.4 & -4.2 & -22.2 \\
MENAP oil importers & -5.7 & -7.4 & -17.0 \\
MENAP oil exporters & -3.0 & -8.4 & -16.8 \\
GCC & -27.5 & -2.4 & -31.2 \\
Maghreb & -13.2 & -2.9 & -19.6 \\
Mashreq & -9.4 & -21.7 & -32.7 \\
CCA & -9.1 & -13.7 & -24.4 \\
CCA oil importers & -9.4 & -23.1 & -34.1 \\
CCA oil exporters & & & \\
\hline Long run & -2.6 & -2.0 & -6.0 \\
MENAP & -4.3 & -1.4 & -7.1 \\
MENAP oil importers & -1.8 & -2.4 & -5.5 \\
MENAP oil exporters & -1.0 & -2.7 & -5.4 \\
GCC & -8.8 & -0.8 & -10.0 \\
Maghreb & -4.2 & -0.9 & -6.3 \\
Mashreq & -3.0 & -7.0 & -10.5 \\
CCA & -2.9 & -4.4 & -7.8 \\
CCA oil importers & -3.0 & -7.4 & -11.0 \\
CCA oil exporters & C &
\end{tabular}

${ }^{1}$ Based on comparison between October 2010 and October 2013 editions of the World Economic Outlook database.

Figure 8: Export Loss from Revisions to Global Growth

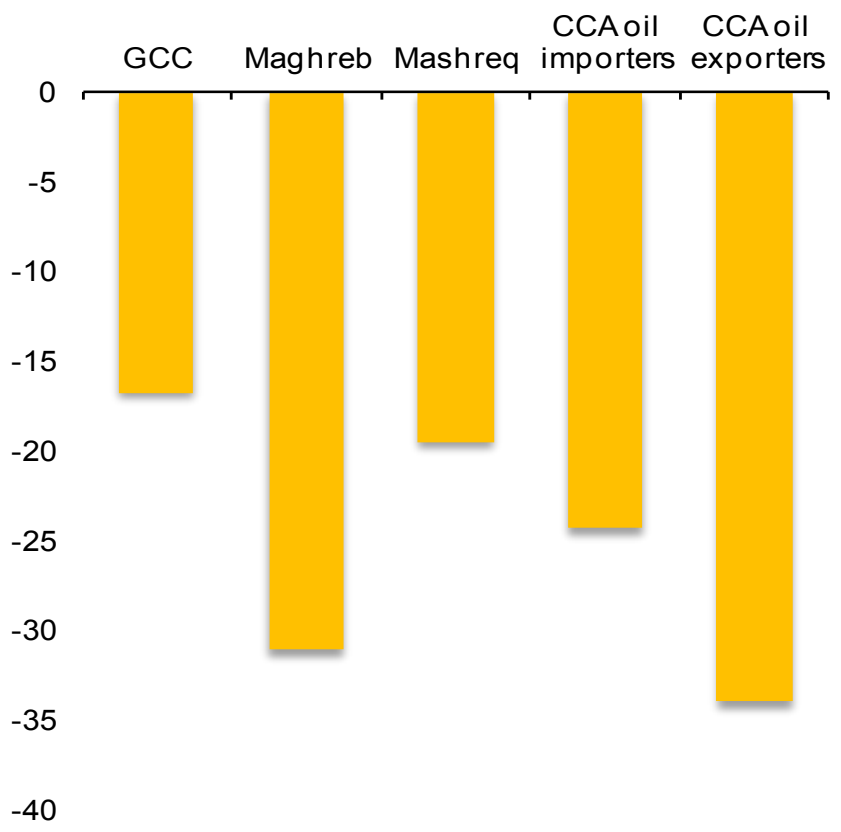


57. A difficult external environment has increased the challenges of transition. Since 2011, many countries in the region have been undergoing a process of difficult political transition amid regional uncertainty. By reducing the scope for export-led recovery, these global-slowdowns are providing stronger than expected headwinds, especially for the Maghreb countries. In particular, our estimates indicate that the worse-than-expected slowdown in Europe and emerging markets has already had a negative impact on non-petroleum exports from MCD. Furthermore, many of these countries are dependent on tourism, which has suffered from regional uncertainty but also from weak global demand. Assuming services have the same geographical distribution as non-oil exports, the MENAP countries may have lost about 61/2 percent in 2011-2014. Given the lower elasticity with respect to foreign GDP and the high sensitivity of a region's tourist arrivals to that region's uncertainty, it is likely that foreign demand has made a smaller contribution to disappointing tourism than is the case for non-oil goods. Similarly, the CCA countries have an estimated cumulative loss of $11 \frac{1 / 2}{2}$ percent, which is substantial yet lower than for non-oil goods.

\section{CONCLUSION}

58. Despite a shift in orientation towards Asia and other fast-growing regions, Europe remains an important export destination for much of the Middle East, North Africa, Caucasus and Central Asia. Maghreb countries send a large proportion of their goods to Europe, as do those in the CCA, who are also exposed to Russia and increasingly to China. Countries in the Mashreq and GCC send large shares of their products to other MCD countries.

59. The global financial crisis and more recent downward revisions to global growth have had a negative impact on MCD exports. Non-oil exports halved after the collapse of Lehman Brothers. They rebounded for many MCD countries but recovery was halted in 2011. While, for some countries, domestic and regional developments associated with the Arab Spring played a role in the disappointing export performance, the global environment became less supportive than previously anticipated. Downward revisions to trading-partner GDP growth may have slowed annual non-oil export growth by an estimated 2 percent per year. Cumulative losses for 2011-14 in the Maghreb countries, many of which are undergoing difficult political transitions, may amount to 3 percent per year, mostly because of revisions to the outlook for Europe. Difficulties in Europe have been compounded by the downward revisions in the BRICS countries in 2011-14; these have been substantial enough to cost the CCA countries about four months of non-oil exports.

60. The Maghreb would be most susceptible to downside risks emanating from Europe. Non-delivery on policy commitments presents continued downside risks to the growth outlook for Europe. Because of strong direct trade links, the two slow-growth scenarios indicate that Maghreb non-oil exports could fall by $23 / 4$ percent for every percentage point shock to GDP in Europe. In the case of an acute intensification of financial stress in the euro 
area, non-oil exports from the Maghreb could be 71/2 percent lower than the baseline in each of the first two years following the shock. The CCA countries have an elasticity of about $1 \frac{114}{4}$ because of smaller but substantial direct exposures to Europe, as well as links with Russia. For other countries in the region, the export effects are to a large extent indirectly felt through the induced slowdowns elsewhere in the world.

61. CCA countries would be most affected by a slowdown in the BRICS. Following slower-than-anticipated growth in emerging markets, there are continued concerns about a hard-landing in some BRICS or other emerging market economies. The CCA countries, especially the oil exporters, would experience comparatively large drops in non-oil exports. The scenario indicates that cumulative export losses could be 12 percent over two years, which implies an elasticity with respect to the BRICS GDP shock of about $1 \frac{1}{2}$. This is about twice the estimated impact for the MENAP countries, which in turn is roughly equally attributable to direct BRICS exposures and indirect exposures to an induced slowdown in Europe.

62. Services and oil export volumes would also fall, but probably by less. Services exports are more resilient to trading partner GDP than non-oil goods exports. On the assumption that services exports have the same geographical distribution as non-oil goods exports, the responsiveness of services to realized and potential GDP shocks is about one third that of nonoil goods. Most oil exporters try to produce at full capacity, but some major producers could reduce oil export volumes in response to a negative shock to global oil demand. Depending on the nature of the supply response, all oil exporters would see export values fall as a result of lower oil prices.

63. Our estimates are conservative. The impact would be larger if:

- $\quad$ The export response matched that of the previous crisis rather than the average trade responsiveness of recent history. Our econometric estimate of the non-oil export response to trading partner GDP of 3.3 is a measure of the average trade response since the mid 1990s. However, it is not improbable that a similar response as that in the Lehman crisis would occur, especially since the restraint practiced in imposing protectionist measures is not to be taken for granted and measures taken to continue trade finance are not guaranteed.

- We allowed for lower MCD GDP to reduce intra-regional trade. Our results are best interpreted as the external-shock impact on exports. Intra-regional exports would also fall. This could be an important factor for many Mashreq and GCC countries. Furthermore, there would be small additional falls induced by the other parts of the world that, because of data deficiencies are not explicitly modeled. 
64. Our estimates do not allow for price competitiveness. The gravity literature typically does not control for exchange rate or price competitiveness effects. The emphasis of the exercises in this paper is the geographical distribution of exports, and we have been able to use readily available results from global macroeconomic models as GDP shocks to input into our simulations. Estimates of the responsiveness of trade to the real exchange rate in MCD are contained in Hakura \& Billmeier (2008). Nonetheless, future work could usefully try an alternative estimation approach that specifies export demand and supply equations as a function of GDP, prices (proxied if necessary by the effective exchange rate), and other variables (Goldstein and Khan, 1985). Combining these estimates with available shocks to trading partner growth and competitiveness, as well as an endogenous response of competitiveness in MCD countries, would refine our understanding of the transmission of shocks to the region.

65. A given change in exports would have the biggest effects on countries with high nonoil export-to-GDP ratios and with limited capacity to absorb external sector shocks. The oil exporters generally have larger export-to-GDP ratios than the oil importers, but only a small ratio of non-oil exports to GDP. Most of the oil exporters countries could withstand shocks of the nature described in this paper, albeit with some damage to fiscal and external balances on account of lower oil prices. For the CCA oil importers, non-oil goods and services exports are about a quarter of GDP. Many of these countries have not adequately rebuilt their buffers after drawing on them during the global financial crisis. For the MENAP oil importers, nonoil goods and services exports amount to approximately one third of GDP. A large number of MENAP countries have run down their reserves in response to social pressures and reduced access to external financing, and currently have output gaps. As a result, global GDP shocks and the resulting export losses could have important and untimely negative effects on aggregate demand and reserves.

66. The region is only moderately synchronized with global developments, but GDP would be negatively affected. Besides trade, global shocks can be transmitted through a number of channels. As discussed in IMF (2013d), remittances are important for the region's oil-importing countries, but financial links are with some exceptions limited. Despite growing linkages, the MCD region as a whole is only moderately integrated with the rest of the world. Calibrations of the IMF's EMERGMOD and of Cashin and others (2012) suggest that growth $1 / 2$ percent below baseline in Europe would reduce MCD GDP by less than 0.1 percent in the first year; of course, a more acute shock would have a bigger effect. Similar calibrations indicate that a BRICS shock (of about $3 \frac{1}{2}$ percent) would result in a GDP loss of about $1 / 2$ percent in the first year for MCD oil importers. EMERGMOD indicates that the MCD oil exporters' GDP loss would be slightly above 1 percent while calibrations of Cashin and others (2012) suggest the effect for MENA oil exporters only would be about $3 / 4$ percent, which implies higher effects on the CCA oil exporters. 


\section{REFERENCES}

Abdih, Y., A. Barajas, R. Chami and C. Ebeke, 2012, "Remittances Channel and Fiscal Impact in the Middle East, North Africa, and Central Asia," IMF Working Paper WP/12/104 (Washington: International Monetary Fund).

Abiad, A., P. Mishra and P. Topalova, 2010, "Do Financial Crises Have Lasting Effects on Trade?" Chapter 4 in World Economic Outlook: October 2010 (Washington: International Monetary Fund).

Albino-War, M., C. Caceres, M. Colacelli, N. Ilahi, D. Kim, A. Shahmoradi and G. Srour, 2012, "Output and Banking Spillovers from Russia and the Euro Area to the CIS and Baltic Countries," Seminar Presentation (July).

Altomonte, Carlo and G.I.P. Ottaviano, 2009, "Resilient to the Crisis? Global Supply Chains and Trade Flows," available at www.VoxEU.org, Center for Economic Policy Research (November).

Anderson, James E. and E. van Wincoop, 2003, "Gravity with Gravitas: A Solution to the Border Puzzle," American Economic Review, 93(1): 170-192.

Anderson, James E., C. Milot, Y. Yotov, 2012, "How Much Does Gravity Deflect Services Trade?" (Philadelphia: Drexel University).

Arellano, M. and S. Bond, 1991, "Some Tests of Specification for Panel Data: Monte Carlo Evidence and an Application to Employment Equations," Review of Economic Studies, 58(2).

Baldwin, R., 2009, The Great Trade Collapse: Causes, Consequences and Prospects, available at www.VOXEU.org, Centre for Economic Policy Research.

Babetskii, I., O. Babetskaia-Kukharchuk and M. Raiser, 2003, "How deep is your trade? Transition and international integration in Eastern Europe and the former Soviet Union, EBRD Working Paper (London).

Behar, Alberto, 2013, "International Linkages and Spillovers for MENAP and CCA," in Annex 2, Middle East and Central Asia Regional Economic Outlook (Washington: International Monetary Fund).

Behar, A. and C. Freund, 2011, "The Trade Performance of the Middle East and North Africa," World Bank MENA Region Working Paper Series No. 53 (Washington: World Bank).

Bems, R., R. Johnson and K. Yi, 2010, "Demand Spillovers and the Collapse of Trade in the Global Recession”, IMF Economic Review, Vol. 58, No. 2.

Berument, H. and N. B. Ceylan, 2008, "US Monetary Policy Surprises and Foreign Interest Rates: Evidence from a Set of MENA Countries," Review of Middle East Economics and Finance, Vol. 4, No. 2, pp. 1-46. 
Borchert, I. and A. Mattoo, 2009, "The Crisis-Resilience of Services Trade", World Bank Policy Research Working Paper No. 4917 (Washington: World Bank —Development Research Group) (May).

Cashin, P., K. Mohaddes and M. Raissi, 2012, "The Global Impact of the Systemic Economies and MENA Business Cycles," IMF Working Paper WP/12/255 (Washington: International Monetary Fund).

Chalk, N., J. Felman, R. Bems, M. Nabar and S. Roache, 2012, "Where is China's External Trade Surplus Heading?" Joint Asia and Pacific Department and Research Department paper (Washington: International Monetary Fund).

Freund, Caroline, 2009, "The Trade Response to Global Downturns-Historical Evidence," World Bank Policy Research Working Paper 5015 (Washington: World Bank).

Gregory, R., C. Henn, B. McDonals and M. Saito, 2010, "Trade and the Crisis: Protect or Recover, IMF Staff Position Note SPN/10/07 (Washington: International Monetary Fund).

Goldstein, M. and M. Khan, 1985, "Income and price effects in foreign trade," in: R. W. Jones \& P. B. Kenen (ed.), Handbook of International Economics, Edition 1, Volume 2.

Hakura, D. and A. Billmeier, 2008, "Trade Elasticities in the Middle East and Central Asia: What is the Role of Oil?" IMF Working Paper WP/08/216 (Washington: International Monetary Fund).

Head K. and T. Mayer, 2013, “Gravity Equations: Workhorse, Toolkit, and Cookbook, in Gopinath, Helpman and Rogoff (eds.), Handbook of International Economics, Vol. 4, Elsevier.

International Monetary Fund, 2011, Middle East and Central Asia Regional Economic Outlook: April 2011 (Washington: International Monetary Fund). Monetary Fund).

2012a, World Economic Outlook: April 2012 (Washington: International 2012b, Middle East and Central Asia Regional Economic Outlook: November 2012 (Washington: International Monetary Fund). Monetary Fund).

2013a, World Economic Outlook: October 2013 (Washington: International 2013b, 2013 Spillover Report, IMF Policy Paper (Washington: International Monetary Fund).

2013c, World Economic Outlook: April 2013 (Washington: International Monetary Fund). 
2013d, Middle East and Central Asia Regional Economic Outlook: November

2013 (Washington: International Monetary Fund).

Irwin, Douglas, 2002, "Long-run trends in world trade and income," World Trade Review, Department of Economics (New Hampshire: Dartmouth College).

Jacks, D., C. Meissner and D. Novy, 2011, "Trade Booms, Trade Busts, and Trade Costs," in Baldwin, R (ed), The Great Trade Collapse: Causes, Consequences and Prospects, available at www.VOXEU.org (Centre for Economic Policy Research).

Johnson, R. C. and G. Noguera, 2012, "Accounting for intermediates: Production sharing and trade in value added," Journal of International Economics, Vol. 86, No. 2, pp. 224-236

Levchenko, A., T. Logan and L. Tesar, 2009, "The Collapse of International Trade during the 2008-9 crisis: In Search of the Smoking Gun," IMF Economic Review Vol. 58, No. 2.

Martins, J. and S. Araujo, 2009, The Great Synchronization: What do high-frequency statistics tell us about the trade collapse?", www.VoxEU.org.

Mora, J. and W. Powers, 2009, "Did trade credit problems deepen the great trade collapse?" in Baldwin, R (ed), The Great Trade Collapse: Causes, Consequences and Prospects, available at www.VOXEU.org, (London: Centre for Economic Policy Research).

Nickell, Stephen, 1981, "Biases in Dynamic Models with Fixed Effects," Econometrica, Vol. 49, No. 6 (November), pp. 1417-1427.

Tas, Bedri Kamil Onur, 2010, "Determinants of time varying sensitivity of MENA countries to global shocks: a state space approach," Economic Research Forum (ERF) Working Paper 530 .

Tinbergen, Jan, 1962, "Shaping the World Economy," Twentieth Century Fund, New York.

Vitek, Francis, 2013, "Policy Analysis and Forecasting in the World Economy: A Panel Dynamic Stochastic General Equilibrium Approach,” IMF Working Paper WP/13/253

(Washington: International Monetary Fund). 